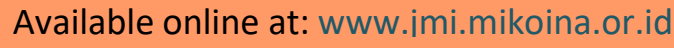 \\ Jurnal Mikologi Indonesia \\ ISSN: $2579-8766$ \\ Online
}

\section{Teknik Memanen Makrokonidia Dermatofita Microsporum gypseum dan Trichophyton mentagrophytes}

\section{Macroconidia Harvesting Techniques in Dermatophytes Microsporum gypseum and Trichophyton mentagrophytes}

\author{
Ana Rufaidah ${ }^{1}$, Eko Sugeng Pribadi², I Ketut Mudite Adnyane ${ }^{3}$ \\ ${ }^{1}$ Mahasiswa Program Pendidikan Profesi Dokter Hewan, Fakultas Kedokteran Hewan, Institut Pertanian Bogor \\ ${ }^{2}$ Divisi Mikrobiologi Medik, Departemen Ilmu Penyakit Hewan dan Kesehatan Masyarakat Veteriner, Fakultas \\ Kedokteran Hewan, Institut Pertanian Bogor \\ ${ }^{3}$ Divisi Anatomi Histologi dan Embriologi, Departemen Anatomi Fisiologi dan Farmakologi, Fakultas \\ Kedokteran Hewan, Institu Pertanian Bogor
}

Rufaidah A, Pribadi ES, Adnyane IKM. 2020 - Teknik Memanen Makrokonidia dari Dermatofita Microsporum gypseum dan Trichophyton mentagrophytes. Jurnal Mikologi Indonesia 4(2), 182-192. doi:10.46638/jmi.v4i2.87

\begin{abstract}
Abstrak
Dermatofitosis adalah penyakit kulit yang disebabkan oleh kapang dermatofita. Penelitian ini bertujuan menentukan teknik yang sesuai untuk memanen makrokonidia dan waktu fase eksponensial Microsporum gypseum dan Trichophyton mentagrophytes. Media 1 dan 2 digunakan untuk pembiakan isolat $M$. gypseum dan T. mentagrophytes. Media 1 mengandung pepton, dekstrosa, dan kloramfenikol dan pada media 2 memiliki komposisi yang sama dengan media 1 dengan tambahan sikloheksamida. Teknik penggoresan pada permukaan koloni dan penggoyangan tabung dengan vortex digunakan untuk memanen makrokonidia. Makrokonidia dipanen pada hari ke 10, 12, 14, 16, 18, dan 20. Hasil yang didapatkan menunjukkan jumlah rata-rata makrokonidia kapang yang dipanen dengan penggoresan pada permukaan koloni lebih tinggi daripada penggoyangan tabung menggunakan vortex selama masa pertumbuhan hingga hari ke-20. Hasil yang didapatkan juga menunjukkan fase eksponensial telah dimulai pada hari ke-14.

Kata kunci - Dermatofita - makrokonidia - Microsporum gypseum - teknik memanen Trichophyton mentagrophytes

Abstract

Dermatophytosis is a fungal infection of the skin caused by Dermatophytes. This study aimed to investigate appropriate techniques to harvest the macroconidia and exponential phase of Microsporum gypseum and Trichophyton mentagrophytes. The media used to cultivate M. gypseum and T. mentagrophytes were media 1 composed of peptone, dextrose agar, chloramphenicol, and media 2 similar to the first media with cycloheximide addition. Scraping technique with oose on the colony's surface and shaking the tube with vortex were used to collect macroconidia. Macroconidia were harvested on days 10,12,14,16,18, and 20. The results showed that the average number of macroconidia collected by the scraping oose on the colony's surface was higher than the one collected by tube shaking with vortex during the growth phases till day 20, with exponential phase started on the $14^{\text {th }}$ day.
\end{abstract}

Keywords - Dermatophytes - macroconidia - harvesting technique - Microsporum gypseum Trichophyton mentagrophytes

Dikirimkan 9 Agustus 2020, Diterima 19 November 2020, Terbit online 15 Desember 2020

Corresponding Author: Ana Rufaidah, e-mail: ananasheer97@gmail.com 


\section{Pendahuluan}

Dermatofitosis atau yang lebih dikenal sebagai penyakit ringworm merupakan penyakit yang disebabkan oleh kapang golongan dermatofita. Penyakit ringworm di Indonesia memiliki tingkat kejadian yang tinggi. Faktor iklim tropis dengan kelembaban yang tinggi merupakan keadaan yang cocok bagi kapang untuk berkembang biak (Kadri, 2017). Menurut Savitri (2010), dermatofitosis merupakan penyakit kulit yang menduduki urutan pertama pada tahun 2002 dibandingkan dengan penyakit kulit lainnya di Indonesia. Kapang Dermatofita terdiri dari genus-genus Microsporum, Trichophyton, dan Epidermophyton (Gholib, 2011). Kapang ini menginfeksi lapisan keratin, mulai dari kulit, kuku, dan rambut (Irimie et al., 2011). Penyakit ini sering ditemukan pada hewan ternak dan hewan kesayangan (anjing dan kucing), serta bersifat zoonotik yang dapat menular ke manusia (Bond, 2010). Penyakit ini dapat menular secara langsung maupun tidak langsung. Menurut Adzima dkk. (2013), penyebaran secara langsung terjadi karena adanya sentuhan dengan kulit, atau rambut yang terinfeksi oleh kapang Dermatofita. Sedangkan penyebaran secara tidak langsung terjadi melalui spora yang terdapat di lingkungan. Gejala klinis yang terlihat jelas pada hewan adalah kerontokan rambut disertai adanya peradangan pada kulit yang berbatas jelas membentuk lingkaran dengan pinggir lesi berkerak dan bersisik (Soeharsono, 2002).

Kapang dermatofita adalah faktor etiologi dari sebagian besar infeksi jamur superfisial, yang membedakannya dari jamur patogen lain yaitu kemampuannya yang unik untuk mendegradasi keratin (Gnat et al., 2020). Kapang berkembang biak baik secara aseksual maupun seksual. Perkembangan hifa membentuk miselium dalam koloni. Menurut Gandjar dkk. (2007), pertumbuhan kapang melalui empat fase, yakni fase lag, fase eksponensial, fase stasioner, dan fase kematian. Fase pertumbuhan kapang dapat ditentukan dengan menghitung jumlah spora maupun jumlah massa sel yang tumbuh (Sanito dkk., 2015).

Fase lag, atau yang biasa dikenal dengan fase penyesuaian (adaptasi), merupakan fase sel cendawan melakukan penyesuaian terhadap kondisi lingkungan. Fase ini dipengaruhi oleh media dan lingkungan pertumbuhan serta jumlah inokulum yang dipindahkan dari media sebelumnya. Fase selanjutnya adalah fase eksponensial yang merupakan tahapan saat kapang akan memperbanyak diri. Kecepatan pertumbuhan pada fase ini sangat dipengaruhi oleh media tempat pertumbuhannya, seperti $\mathrm{pH}$, kandungan nutrisi, suhu, dan kelembaban udara. Kebutuhan energi pada fase ini lebih banyak dibandingkan dengan fase lainnya. Kemudian masuk ke fase stationer yang merupakan keadaan populasi sel berjumlah tetap karena jumlah sel yang tumbuh sama dengan jumlah sel yang mati. Fase yang terakhir adalah fase kematian. Populasi sel pada fase ini mengalami kematian akibat kehabisan nutrisi dan energi (Gandjar dkk., 2007).

Pengenalan dermatofita dilakukan berdasarkan pengamatan talus yang tumbuh di media pembiakan. Bentuknya terdiri dari hifa dan konidia berbentuk makrokonidia dan mikrokonidia. Menurut Shimamura et al. (2012), bentuk dan ukuran makrokonidia dan mikrokonidia serta ketebalan dinding sel adalah struktur yang diidentifikasi untuk melakukan pengenalan genus/spesies. Namun sebagian besar penelitian menggunakan makrokonidia sebagai struktur infektif acuan ketika melakukan infeksi buatan pada hewan (Baltazar et al., 2014). Penelitian ini bertujuan menyampaikan teknik yang sesuai untuk memanen makrokonidia kapang Microsporum gypseum dan Trichophyton mentagrophytes, dan memperlihatkan waktu fase eksponensial pertumbuhan kapang $M$. gypseum dan $T$. mentagrophytes.

\section{Metoda Penelitian \\ Pembuatan Media}

Media yang digunakan dalam penelitian dibuat menjadi dua media berbeda berbentuk agar miring dalam tabung. Media 1 bahan penyusunnya terdiri dari pepton 1\%, dekstrosa 4\%, dan agar 1,5\% yang dicampur dalam air suling sucihama sebanyak 95,0 mL. Campuran 
disucihamakan menggunakan autoclave dengan suhu $121{ }^{\circ} \mathrm{C}$ selama 15 menit. Setelah disucihamakan, media 1 diangkat dan diaduk di atas bak air sampai mencapai suhu $60^{\circ} \mathrm{C}$, kemudian diimbuhi antibiotika kloramfenikol. Media 2 dibuat dengan bahan penyusun yang sama dengan media 1, tapi kandungan dekstrosa hanya 2\%, dan diimbuhi dengan antibiotika sikloheksamida dan kloramfenikol.

\section{Penyegaran Isolat Dermatofita}

Isolat $T$. mentagrophytes dan $M$. gypseum yang merupakan isolat arsip laboratorium Mikrobiologi Medik FKH IPB disegarkan kembali dengan cara dibiakkan ulang pada media 1 dan media 2 dalam bentuk agar miring dengan jumlah biakan masing-masing sebanyak 212 batang tabung pada masing-masing media. Seluruh biakan diinkubasi pada suhu kamar selama 20 hari dan diamati setiap hari dengan keutamaan pengamatan pada hari ke-10, 12, 14, 16, 18, dan 20 untuk mengamati pertumbuhan kapang.

\section{Pengenalan Ulang}

Pengenalan ulang kapang dermatofita dilakukan secara makro dan mikroskopik. Pemeriksaan secara makroskopik meliputi lamanya pertumbuhan, pengamatan warna koloni, morfologi, bentuk, dan permukaan bawah koloni. Pemeriksaan secara mikroskopik dilakukan dengan menggunakan Lactophenol Cotton Blue (LPCB) dengan menggoreskan jarum ose pada koloni kapang yang tumbuh dan diusapkan pada gelas objek yang telah ditetesi LPCB, lalu ditutup dengan gelas penutup. Kemudian dilakukan pemeriksaan menggunakan mikroskop untuk melihat adanya hifa, makrokonidia, dan mikrokonidia (Nasimuddin et al., 2014).

\section{Penghitungan Makrokonidia}

Penghitungan makrokonidia dilakukan mengikuti Puspitasari (2014). Penghitungan makrokonidia dilakukan dengan membuat suspensi endapan makrokonidia. Sebanyak sembilan mililiter air suling sucihama ditambahkan ke atas agar miring. Dua teknik perlakuan digunakan untuk memanen makrokonidia dari koloni kapang yang tumbuh, yaitu (a) dengan menggoreskan jarum ose pada permukaan koloni (Gambar 1), dan (b) menggoyangkan tabung dengan bantuan alat penggoyang (vortex).

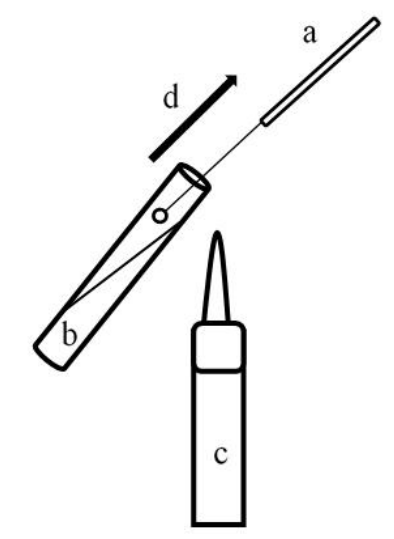

Gambar 1. Skema teknik penggoresan menggunakan jarum ose. Penggoresan dilakukan dengan menggoreskan jarum ose pada permukaan koloni secara vertikal searah mulut tabung. (a) jarum ose, (b) tabung reaksi berisi koloni kapang, (c) pembakar bunsen, (d) arah penggoresan. 
Kemudian seluruh air suling ditumpahkan dan ditampung dengan tabung reaksi kecil sucihama. Sebanyak satu tetes dipindahkan ke dalam ruang hitung mikro (counting chamber) dan dilakukan penghitungan sel makrokonidia sehingga dapat dihitung sebanyak $z$ sel pada kotak hitung seperti yang terlihat pada (Gambar 2). Jumlah sel makrokonidia yang dapat dihitung dimasukkan ke dalam rumus:

$$
\frac{\text { z sel }}{\text { volume kamar hitung }}=\text { jumlah sel makrokonidia dalam tabung } / \mathrm{mL}
$$

Jika dalam perhitungan pertama di atas, ternyata jumlah sel makrokonidia terlalu padat sehingga tidak bisa dihitung, maka suspensi makrokonidia awal diencerkan menggunakan pengenceran desimal $\left(10^{-1}\right)$. Sebanyak satu mililiter suspensi makrokonidia ditambahkan ke dalam tabung reaksi yang telah berisi sembilan mililiter air suling sucihama. Pengenceran dilakukan berulang hingga diperoleh pengenceran $10^{-3}$. Penghitungan sel makrokonidia dilakukan seperti di atas. Hasil perhitungan mikroskopik di atas dimasukkan ke dalam rumus:

$$
\frac{z \text { sel }}{\text { volume kamar hitung }} x \text { faktor pengencer }=\Sigma \text { sel makrokonidia dalam tabung } / \mathrm{mL}
$$

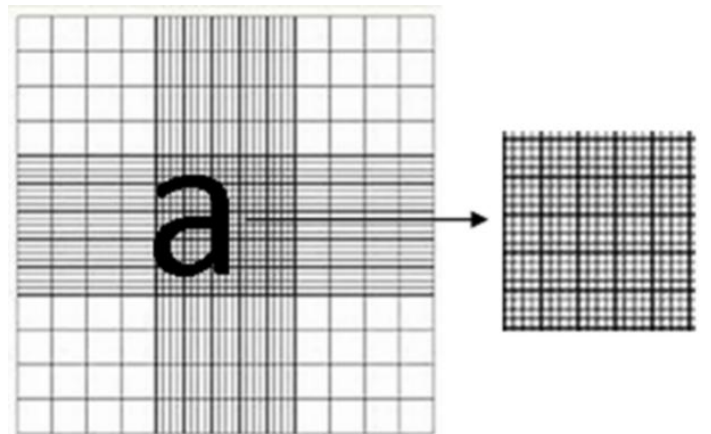

Gambar 2. Kotak Penghitungan makrokonidia pada ruang hitung mikro (counting chamber). Volume kamar hitung (a) $0,0001 \mathrm{~mL}$

\section{Pengolahan Data}

Data jumlah makrokonidia dianalisis secara statistik menggunakan SPSS 24, yakni Dependent sample t-test, atau yang biasa dikenal dengan paired sample t-test yang bertujuan untuk membandingkan rata-rata jumlah makrokonidia yang menggunakan media 1 dengan dan tanpa penggoresan, serta media 2 dengan dan tanpa penggoresan untuk masing-masing isolat. Kemudian, data di atas akan dimasukkan ke dalam bentuk grafik garis untuk melihat kurva pertumbuhan kapang pada masing-masing media.

Jika dalam perhitungan pertama di atas, ternyata data jumlah sel makrokonidia tidak menyebar secara normal maka akan dilakukan perhitungan menggunakan Wilcoxon signed rank test yang merupakan uji non parametrik untuk mengukur taraf perbedaan antara kelompok data yang diperoleh. Pengukuran panjang dan lebar makrokonidia dilakukan secara kuantitatif menggunakan perangkat lunak Image $J^{\mathbb{B}}$ dengan mengambil sampel sebanyak 30 makrokonidia setiap isolat yang kemudian dihitung rata-ratanya.

\section{Hasil}

\section{Identifikasi Isolat Dermatofita}

Pertumbuhan kapang terlihat pertama kali pada hari ke-8 dengan terlihat adanya serat putih seperti kapas di permukaan media. Berdasarkan pengamatan secara makroskopik, isolat kapang T. mentagrophytes yang tumbuh memperlihatkan koloni berwarna putih sampai putih 
kekuningan dan tengah koloni berwarna putih krem. Topografi isolat kapang $T$. mentagrophytes adalah datar dengan permukaan membentuk bubuk hingga berbutir, membentuk lipatan ditengah dengan tekstur seperti kapas (Gambar 3a). Sedangkan isolat kapang $M$. gypseum yang tumbuh memperlihatkan koloni berwarna coklat dengan bagian tengah berwarna putih kecoklatan dan bagian bawah koloni berwarna krem kekuningan sampai coklat merah. Topografi isolat kapang $M$. gypseum adalah datar, membentuk tonjolan di tengah, menyebar secara radial di bagian tepi, dan tekstur diawal pertumbuhan seperti bulu halus yang selanjutnya berubah menjadi berbutir (Gambar 3b). Karakter pertumbuhan kedua isolat kapang tersebut terlihat sama, baik yang tumbuh di atas media 1 maupun 2 .

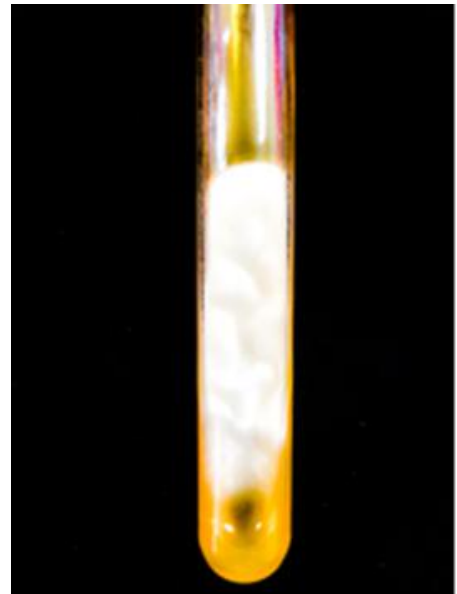

(a)

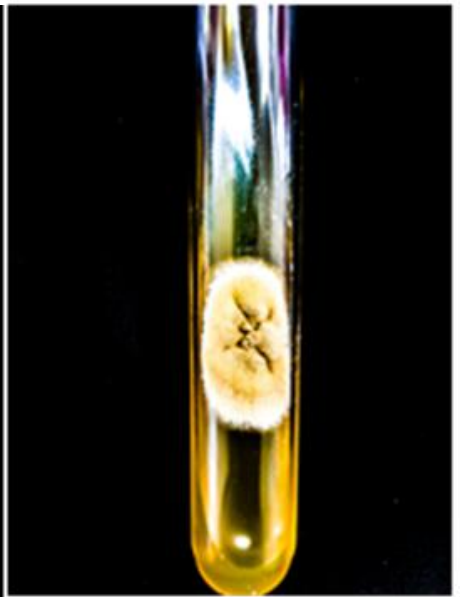

(b)

Gambar 3. Hasil pengamatan secara makroskopis isolat T. mentagrophytes dan $M$. gypseum yang dibiakkan dalam media 2 yang dimodifikasi pada masa inkubasi 14 hari (a) tekstur koloni isolat T. mentagrophytes seperti kapas dan (b) isolat M. gypseum membentuk tonjolan di tengah dengan tekstur berbutir.

\section{Karakteristik makrokonidia}

Hasil pengamatan secara mikroskopik isolat T. mentagrophytes dan M. gypseum yang tumbuh memiliki struktur makrokonidia yang berbeda. Kapang $T$. mentagrophytes memperlihatkan struktur makrokonidia yang jarang dengan ukuran kecil berbentuk seperti cerutu (Gambar 4a). Sedangkan makrokonidia T. mentagrophytes memiliki dinding tipis dan halus, serta memiliki ukuran panjang 17,66 $\pm 3,29 \mu \mathrm{m}$, lebar 5,85 $\pm 2,54 \mu \mathrm{m}$. Sedangkan makrokonidia $M$. gypseum memperlihatkan susunan dinding yang tipis, kasar, dan memiliki 4-6 septa berbentuk oval dengan ukuran yang besar, yakni panjangnya $56,59 \pm 14,20 \mu \mathrm{m}$ dan lebarnya 13,38 $\pm 2,95 \mu \mathrm{m}$ (Gambar 4b).

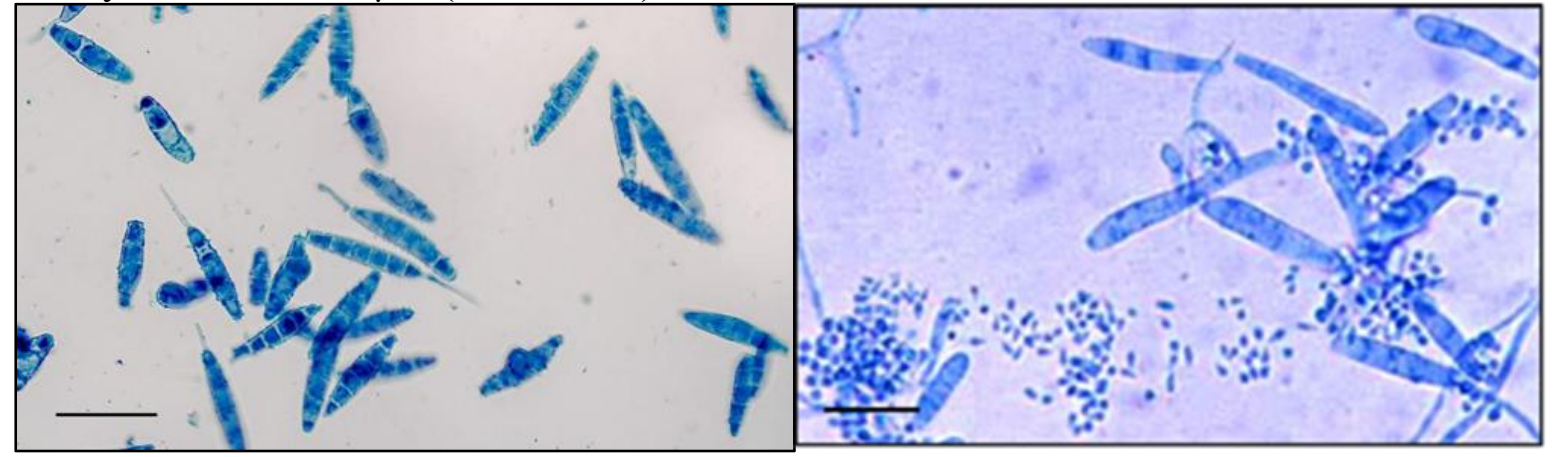

(a) (b)

Gambar 4. Hasil pengamatan secara mikroskopis isolat T. mentagrophytes dan M. gypseum yang dibiakkan dalam media 2 yang dimodifikasi pada masa inkubasi 14 hari (a) makrokonidia isolat $T$. mentagrophytes memiliki ukuran kecil berbentuk cerutu. Pembesaran okuler: $100 \times$. Skala $=250 \mu \mathrm{m}$, dan (b) makrokonidia isolat M. gypseum 
memiliki 4-6 septa berbentuk oval dengan ukuran yang cukup besar. Pembesaran okuler $=40 \times$. Skala $=250 \mu \mathrm{m}$.

\section{Pemanenan Makrokonidia}

Tabel 1 menunjukkan jumlah makrokonidia kapang $T$. mentagrophytes dan $M$. gypseum yang dipanen menggunakan teknik penggoresan dengan jarum ose lebih banyak dibandingkan dengan teknik penggoyangan tabung menggunakan alat vortex. Hal ini juga ditunjukkan dengan jumlah makrokonidia yang terus meningkat pada setiap pemanenan dengan teknik penggoresan jarum ose $(p<0,05)$.

Tabel 1. Rata-rata jumlah makrokonidia yang dipanen menggunakan dua teknik pemanenan yang dibiakkan di atas media 1 dan media 2

\begin{tabular}{|c|c|c|c|c|c|c|c|c|}
\hline \multirow[t]{2}{*}{ Isolat } & \multirow{2}{*}{$\begin{array}{l}\text { Media } \\
\text { Tumbuh }\end{array}$} & \multirow{2}{*}{$\begin{array}{l}\text { Teknik } \\
\text { Panen }\end{array}$} & \multicolumn{6}{|c|}{$\begin{array}{l}\text { Rerata Jumlah Makrokonidia Selama Masa Inkubasi (Hari Ke-) } \\
\qquad\left(n \text { unit x } 10^{4} \text { makrokonidia/mL) }\right.\end{array}$} \\
\hline & & & 10 & 12 & 14 & 16 & 18 & 20 \\
\hline \multirow{4}{*}{ TM } & \multirow{2}{*}{ Media $1^{\mathrm{a}}$} & $\mathrm{A}^{* *}$ & $2,33 \pm 0,58^{\mathrm{d}}$ & $0,33 \pm 0,58^{\mathrm{f}}$ & $1,0 \pm 0,0^{\mathrm{e}}$ & $16,67 \pm 1,53^{\mathrm{c}}$ & $43,33 \pm 1,53^{b}$ & $243,3 \pm 15,3^{\mathrm{a}}$ \\
\hline & & $\mathrm{B}^{*}$ & $1,33 \pm 0,58^{\mathrm{d}}$ & $0,0 \pm 0,58^{\mathrm{f}}$ & $0,33 \pm 0,58^{\mathrm{e}}$ & $8,33 \pm 0,58^{\mathrm{c}}$ & $17,0 \pm 1,0^{\mathrm{b}}$ & $32,67 \pm 1,15^{\mathrm{a}}$ \\
\hline & \multirow{2}{*}{$\operatorname{Media} 2^{a}$} & $\mathrm{~A}^{* *}$ & $1,67 \pm 0,58^{\mathrm{e}}$ & $1,67 \pm 1,53^{\mathrm{e}}$ & $3,67 \pm 0,47^{\mathrm{d}}$ & $34,0 \pm 0,0^{c}$ & $120,0 \pm 0,0^{\mathrm{b}}$ & $460,0 \pm 0,0^{\mathrm{a}}$ \\
\hline & & $\mathrm{B}^{*}$ & $3,67 \pm 0,58^{\mathrm{d}}$ & $0,33 \pm 0,58^{\mathrm{f}}$ & $0,67 \pm 0,58^{\mathrm{e}}$ & $14,67 \pm 0,58^{\mathrm{c}}$ & $39,0 \pm 1,0^{\mathrm{b}}$ & $72,33 \pm 0,58^{\mathrm{a}}$ \\
\hline \multirow{4}{*}{ MG } & \multirow{2}{*}{ Media $1^{\mathrm{a}}$} & $A^{* *}$ & $10,67 \pm 0,58^{\mathrm{e}}$ & $7,67 \pm 0,58^{\mathrm{f}}$ & $34,67 \pm 2,52^{d}$ & $66,0 \pm 1,0^{c}$ & $160,0 \pm 0,0^{\mathrm{b}}$ & $346,7 \pm 5,77^{\mathrm{a}}$ \\
\hline & & $\mathrm{B}^{*}$ & $1,67 \pm 0,58^{\mathrm{e}}$ & $1,0 \pm 0,0^{\mathrm{f}}$ & $11,33 \pm 1,15^{\mathrm{d}}$ & $25,67 \pm 1,53^{\mathrm{c}}$ & $32,0 \pm 0,0^{\mathrm{b}}$ & $48,67 \pm 0,58^{\mathrm{a}}$ \\
\hline & \multirow{2}{*}{ Media $2^{b}$} & $\mathrm{~A}^{* *}$ & $5,0 \pm 0,0^{\mathrm{e}}$ & $2,33 \pm 0,58^{\mathrm{f}}$ & $44,33 \pm 0,58^{\mathrm{d}}$ & $87,0 \pm 0,0^{\mathrm{c}}$ & $216,67 \pm 5,78^{b}$ & $590,0 \pm 0,0^{\mathrm{a}}$ \\
\hline & & $\mathrm{B}^{*}$ & $1,33 \pm 0,58^{\mathrm{e}}$ & $0,33 \pm 0,58^{\mathrm{f}}$ & $24,0 \pm 0,0^{\mathrm{d}}$ & $56,67 \pm 1,15^{\mathrm{c}}$ & $74,0 \pm 1,0^{\mathrm{b}}$ & $113,3 \pm 5,77^{\mathrm{a}}$ \\
\hline
\end{tabular}

Keterangan: $\mathrm{TM}=T$. mentagrophytes, $\mathrm{MG}=M$. gypseum, $\mathrm{A}=$ Penggoresan jarum ose, $\mathrm{B}=$ Menggoyangkan tabung menggunakan vortex.

*jumlah tanda bintang yang berbeda pada kedua teknik menunjukkan perbedaan nyata $(\mathrm{p}<0,05)$

*huruf superscript yang berbeda pada baris yang sama menunjukkan perbedaan nyata $(\mathrm{p}<0,05)$.

*huruf superscript yang berbeda pada kedua media menunjukkan perbedaan yang nyata $(\mathrm{p}<0,05)$.

\section{Laju Pertumbuhan Makrokonidia}

Hasil pengamatan selama pertumbuhan sampai hari ke-20 telah menunjukkan pertumbuhan fase lag dan fase eksponensial. Fase lag terjadi selama 14 hari sejak pembiakkan. Selama fase ini, sel-sel cendawan mengalami masa penyesuaian diri terhadap keadaan lingkungan yang baru ditandai dengan naik turunnya jumlah makrokonidia selama fase ini seperti yang terlihat pada hari ke-12 dan mulai meningkat kembali pada hari ke-14. Hari berikutnya merupakan fase eksponensial yang ditandai dengan peningkatan jumlah makrokonidia yang terhitung mengalami pertambahan yang nyata $(p<0,05)$ seperti yang diperlihatkan dalam (Gambar 5).

\section{Pembahasan}

Pertumbuhan kapang dermatofita dalam pembiakan di atas media agar sangat dipengaruhi faktor dalam maupun faktor luar. Faktor dalam yang sangat berpengaruh adalah adanya karbohidrat yang menjadi sumber utama metabolisme kapang (Retnowati dkk., 2010). Menurut Ahdy et al. (2016), faktor luar yang mempengaruhi kapang dermatofita tumbuh dengan baik adalah kondisi lingkungan dengan suhu $25-27^{\circ} \mathrm{C}$, kelembaban yang tinggi, dan ketersediaan oksigen. Pertumbuhan kapang dinilai berdasarkan ciri-ciri sudah terbentuknya hifa yang dilihat menggunakan mikroskop. Hifa merupakan struktur dasar kapang yang berbentuk seperti tabung. 
Pertumbuhan dermatofita memiliki kurva normal yang terdiri dari empat fase. Fase awal adalah fase lag yang merupakan fase ketika sel kapang sedang menyesuaikan dirinya terhadap keadaan lingkungan yang baru. Fase ini yang menentukan kapang dapat tumbuh atau tidak. Kapang yang sudah berhasil menyesuaikan dirinya selanjutnya masuk ke dalam fase memperbanyak diri yakni, fase eksponensial. Fase ini merupakan fase yang biasanya digunakan oleh peneliti untuk membuat infeksi buatan pada hewan coba. Dua berikutnya adalah fase stationer dan fase kematian.

Pertumbuhan kapang terlihat pertama kali pada hari ke-8 dengan terlihat adanya serat putih seperti kapas di permukaan media (Gambar 3). Berdasarkan pengamatan secara makroskopik, isolat kapang T. mentagrophytes yang tumbuh memperlihatkan koloni berwarna putih sampai putih kekuningan dan tengah koloni berwarna putih krem. Topografi isolat kapang T. mentagrophytes adalah datar dengan permukaan membentuk bubuk hingga berbutir, membentuk lipatan ditengah dengan tekstur seperti kapas (Gambar 3a) (AHP, 2016).

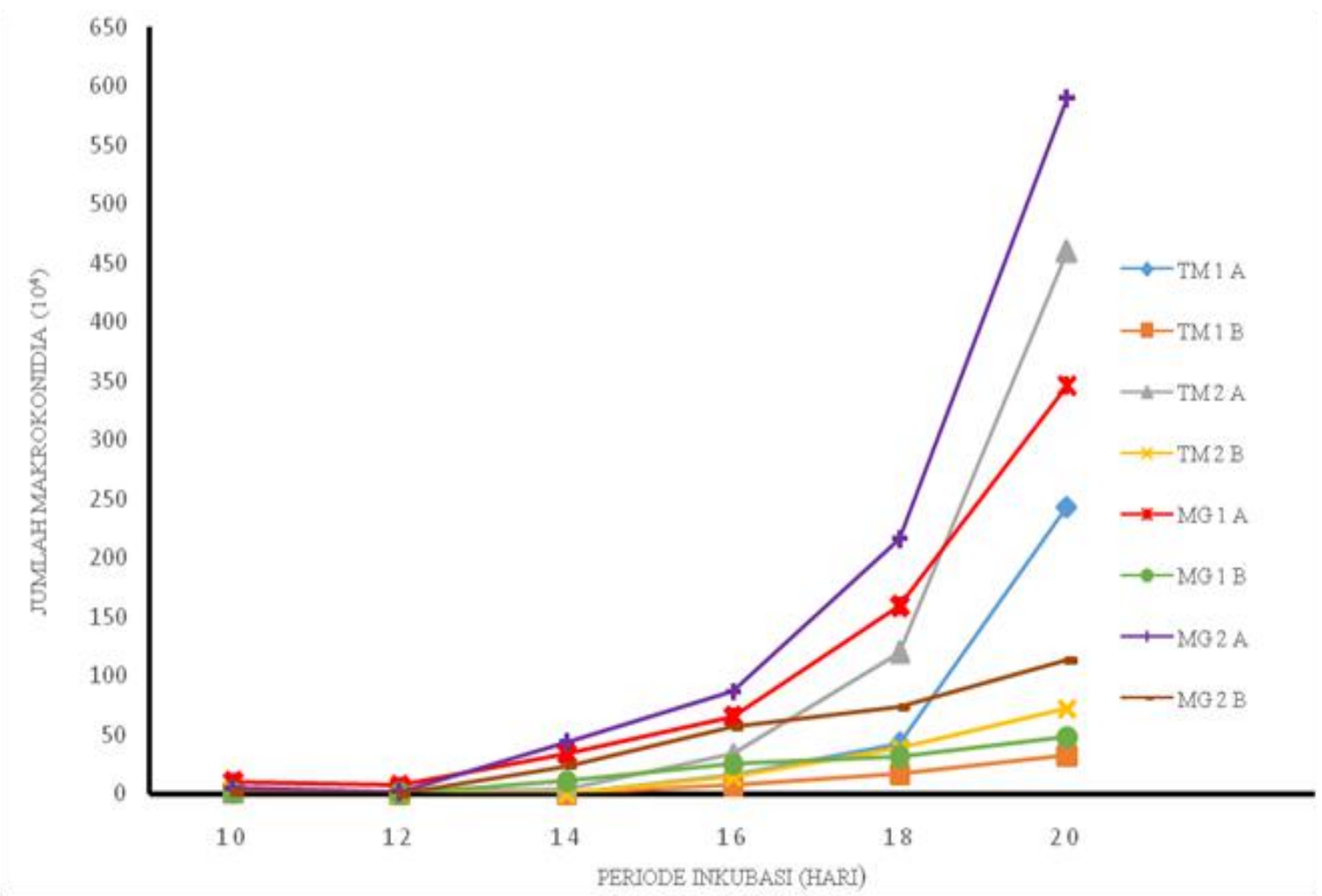

Keterangan: $\mathrm{TM}=T$. mentagrophytes, $\mathrm{MG}=M$. gypseum, $1=$ Media $1,2=$ Media 2, $\mathrm{A}=$ Penggoresan menggunakan jarum ose, $\mathrm{B}=$ Menggoyangkan tabung menggunakan alat vortex

Gambar 5. Fase pertumbuhan kapang T. mentagrophytes dan M. gypseum selama 20 hari dalam media 1 dan media 2.

Isolat kapang $M$. gypseum yang tumbuh memperlihatkan koloni berwarna coklat dengan bagian tengah berwarna putih kecoklatan dan pada bagian bawah koloni berwarna krem kekuningan sampai coklat merah. Topografi isolat kapang M. gypseum adalah datar, membentuk tonjolan di tengah menyebar secara radial di bagian tepi, dan tekstur diawal pertumbuhan seperti bulu halus yang selanjutnya berubah menjadi berbutir (Gambar 3b). Hasil yang sama juga diperoleh Putriningsih \& Arjentinia (2018). Karakter pertumbuhan kedua isolat kapang tersebut terlihat sama, baik yang tumbuh di atas media 1 maupun media 2.

Pemanenan makrokonidia mulai dilakukan pada hari ke-10 yang diharapkan kapang berada pada masa pertumbuhan yang telah optimal. Hasil pengamatan secara mikroskopik terhadap isolat kapang $T$. mentagrophytes dan M. gypseum yang tumbuh memiliki struktur 
makrokonidia yang cukup berbeda. Kapang T. mentagrophytes memperlihatkan struktur makrokonidia yang jarang dengan ukuran kecil berbentuk seperti cerutu (Gambar 4a) sesuai dengan yang didapatkan oleh Chollet et al. (2015). Makrokonidia kapang T. mentagrophytes memiliki dinding tipis dan halus, serta memiliki ukuran panjang 17,66 $\pm 3,29 \mu \mathrm{m}$, lebar 5,85 $\pm 2,54 \mu \mathrm{m}$, sedangkan makrokonidia $M$. gypseum memperlihatkan susunan dinding yang tipis, kasar, dan memiliki 4-6 septa berbentuk oval dengan ukuran yang cukup besar, yakni panjangnya 56,59 $\pm 14,20 \mu \mathrm{m}$ dan lebarnya 13,38 $\pm 2,95 \mu \mathrm{m}$ (Gambar 4b) (Kurnia, 2015).

Penelitian ini memberlakukan masa inkubasi selama 20 hari. Hal ini didasari oleh penelitian sebelumnya yang menunjukkan pertumbuhan optimal kapang dermatofita tercapai pada minggu ke-2 pasca penanaman dan akan mati di lingkungan pada hari ke-30 akibat kehabisan nutrisi (Emam \& El-salam, 2016). Data hasil penelitian terhadap jumlah makrokonidia yang dipanen dua hari sekali selama 20 hari dengan dua teknik berbeda disajikan dalam Tabel 1.

Data hasil penghitungan jumlah makrokonidia dalam penelitian ini semula akan diolah secara statistik menggunakan metode Paired Sample t-Test. Tetapi, metode ini tidak dapat dilakukan karena data tidak membentuk pola data sebaran normal. Oleh karena itu, analisis statistik dilakukan menggunakan metode Wilcoxon Signed Rank Test.

Tabel 1 menunjukkan jumlah makrokonidia kapang $T$. mentagrophytes dan $M$. gypseum yang dipanen menggunakan teknik penggoresan dengan jarum ose lebih banyak dibandingkan dengan teknik penggoyangan tabung menggunakan vortex. Hal ini juga ditunjukkan dengan jumlah makrokonidia yang terus meningkat pada setiap pemanenan dengan teknik penggoresan oose $(p<0,05)$. Hasil ini memperlihatkan bahwa adanya perlekatan makrokonidia yang sangat kuat pada konidifor sehingga dengan cara menggoyangkan tabung dengan vortex saja tidak akan mampu melepaskan makrokonidia. Menurut Anderson \& Smith (1971), konidiofor merupakan hifa dewasa yang berbentuk tangkai memanjang dan bercabang yang menjadi tempat makrokonidia melekat.

Hasil pengamatan selama pertumbuhan sampai hari ke-20 telah menunjukkan pertumbuhan fase lag dan fase eksponensial. Fase lag terjadi selama 14 hari sejak pembiakan. Selama fase ini, sel-sel cendawan mengalami masa penyesuaian diri terhadap keadaan lingkungan yang baru (Sanito dkk., 2015). Naik turunnya jumlah makrokonidia terlihat selama fase ini seperti yang terlihat pada hari ke-12 dan mulai meningkat kembali pada hari ke-14. Hari berikutnya merupakan fase eksponensial yang ditandai dengan peningkatan jumlah makrokonidia yang terhitung mengalami pertambahan yang nyata $(p<0,05)$ seperti yang diperlihatkan dalam Gambar 5. Penelitian lain menyatakan bahwa pertumbuhan kapang akan mencapai masa optimum pada minggu ke-2 setelah penanaman (Shapourzadeh et al., 2016). Data yang diperoleh dalam Penelitian ini belum bisa menentukan akhir dari fase eksponensial karena peningkatan jumlah makrokonidia masih terus terjadi sampai hari ke 21 dan seterusnya.

Penggunaan media 1 dan media 2 dalam bentuk agar miring bertujuan untuk melihat adanya perbedaan reaksi pertumbuhan kapang terhadap dua media yang berbeda. Media 1 memiliki komposisi menyerupai media Sabouraud's Dextrose Agar (SDA) yang merupakan media umum, digunakan untuk menumbuhkan semua jenis kapang dan khamir dengan adanya antibiotik kloramfenikol untuk menghambat pertumbuhan bakteri (Rosana et al., 2014). Media 2 memiliki komposisi menyerupai media Dermatophyte Selective Agar (DSA) yang merupakan media selektif untuk menumbuhkan kapang Dermatofita karena mengandung antibiotik sikloheksimida (cycloheximide), berfungsi menghambat pertumbuhan kapang saprofit selain adanya antibiotika kloramfenikol (Himedia, 2011). Hasil pertumbuhan pada media 2 lebih cepat terlihat pertumbuhannya dan lebih banyak menghasilkan makrokonidia dibandingkan dengan media 1. Hal ini karena kapang dermatofita lebih 
menyukai keadaan rendah dekstrosa serta adanya sikloheksamida seperti yang terkandung pada media 2.

Penelitian lain menggunakan media agar padat dalam cawan. Perbandingan hasil yang didapat menunjukkan bahwa pertumbuhan kapang pada media agar dalam cawan lebih cepat menyebar dibandingkan dengan media agar miring dalam tabung. Hal ini menafsirkan bahwa pertumbuhan kapang sangat berpengaruh terhadap luasan media. Semakin luas media maka akan semakin cepat penyebaran pertumbuhan kapang. Namun dalam proses pemanenan akan lebih mudah dilakukan jika menggunakan tabung, karena lebih memudahkan dalam proses pengenceran dan pengadukannya. Keuntungan media dalam tabung dapat mengurangi kontaminasi secara langsung terhadap biakan kapang karena bentuk mulut tabung yang lebih sempit dibandingkan dengan cawan yang permukaannya luas. Pemanenan menggunakan tabung lebih menjamin keselamatan peneliti (biosafety) terhadap infeksi saat melakukan pemanenan, dan mengurangi lepasnya spora ke lingkungan (aerosol) (Machmud, 2001).

Teknik memanen makrokonidia dengan cara menggoreskan jarum ose di atas permukaan koloni kapang terbukti secara efektif karena jumlah perolehan makrokonidia lebih banyak dibandingkan tanpa menggoreskan jarum ose terhadap koloni kapang. Teknik ini dapat digunakan sebagai acuan peneliti dalam memanen makrokonidia. Laju pertumbuhan dermatofita terlihat mencapai fase eksponensial dimulai pada hari ke-14. Hasil ini dapat digunakan untuk menentukan fase pertumbuhan kapang yang tepat sesuai dengan jumlah makrokonidia yang dipanen pada 20 hari perlakuan.

\section{Pustaka}

Adzima, V., Jamin, F. \& Abrar, M. (2013). Isolasi dan identifikasi kapang penyebab dermatofitosis pada anjing di kecamatan Syiah Kuala Banda Aceh. Jurnal Medika Veterinaria, 7(1), 46-48. https://doi.org/10.21157/j.med.vet..v7i1.2920

Ahdy, A. M., Ahmed, M. Z. S., Younis, E. E., Baraka, H. N. \& El-Khodery, S. A. (2016). Prevalence and potencial risk factors of dermatophytosis in Arabian horses in Egypt. Journal of Equine Veterinary Science, 37, 71-76. https://doi.org/10.1016/j.jevs.2015.12.008

[AHP] Accelerated Hydrogen Peroxide. (2016). Trichophyton Mentagrophytes. http://info.virox.com/hubfs/VAH_Resources_PDFs/Factsheet_Trichophyton_Mentag rophytes_March2016.pdf(diakses 4 April 2019).

Anderson, J. G. \& Smith, J. E. (1971). The production of conidiophores and conidia by newly germinated conidia of Aspergillus niger (microcycle conidiation). Journal of General Microbiology, 69, 185-197. https://doi.org/10.1099/00221287-69-2-185

Baltazar, L. M., Santos, P. C., Paula, T. P., Rachid, M. A., Cisalpino, P. S., Souza, D. G. \& Santos, D. A. (2014). IFN-gamma impairs Tricophyton rubrum proliferation in a murine model of dermatophytosis through the production of IL-1beta and reactive oxygen species. Medical Mycology, 52, 293-302. https://doi.org/10.1093/mmy/myt011

Bond, R. (2010). Superficial veterinary mycoses. Clinics in Dermatology, 28, 226-236. https://doi.org/10.1016/j.clindermatol.2009.12.012

Chollet, A., Cattin, V., Fratti, M., Mignon, B. \& Monod, M. (2015). Which fungus originally was Tricophyton mentagrophytes: Historical review and illustration by a clinical case. Mycopathologia, 180(2), 1-5. https://doi.org/10.1007/s11046-015-9893-2

Emam, S. M. \& El-salam, O. H. A. (2016). Real-time PCR: A rapid and sensitive method for diagnosis of dermatophyte induced onychomychosis, a comparative study. Alexandria Journal of Medicine, 52(1), 83-90. https://doi.org/10.1016/j.ajme.2015.05.001

Gandjar, I., Sjamsuridzal, W. \& Oetari, A. (2007). Mikologi Dasar dan Terapan. Yayasan Buku Obor. 
Gholib, D. (2011). Uji daya antifungi ekstrak etanol rimpang kencur (Kaemfera galangal L) terhadap pertumbuhan jamur Trycophyton verrucosum secara in vitro. Seminar Nasional Teknologi Peternakan dan Veteriner, Prosiding, 2011, 865-869, Disampaikan pada Seminar Nasional Teknologi Peternakan dan Veteriner, Bogor 2011.

Gnat, S., Lagowski, D. \& Nowakiewicz, A. (2020). Major challenges and perspectives in the diagnostics and treatment of dermatophyte infections. Journal of Applied Microbiology, 129(2), 212-232. https://doi.org/10.1111/jam.14611

Himedia. (2011). Dermathophyte Test Medium Agar Base. http://himedialabs.com/TDM188.pdf (diakses 8 April 2019).

Irimie, M., Tataru, A. \& Oanta A. (2011). Evaluation of real time polymerase chain reaction assay for identification of common Dermatophyte species. Bulletin of The Transilvania University of Brasov, 4(53), 65-72.

Kadri, F.S.D. (2017). Cendawan pencemar di ruang pemandian hewan di beberapa klinik dan toko hewan piara di Kota Bogor, Jawa Barat (Skripsi). Fakultas Kedokteran Hewan, Institut Pertanian Bogor.

Kurnia, K. I. (2015). Aktivitas beberapa antimikotik terhadap Microsporum gypseum sebagai penyebab dermatofitosis pada kuda (Skripsi). Fakultas Kedokteran Hewan, Institut Pertanian Bogor.

Machmud, M. (2001). Teknik penyimpanan dan pemeliharaan mikroba. Buletin Agro Bio, 4(1), 24-32.

Nasimuddin, S., Appalaraju, B., Surendran, P. \& Srinivas, C.R. (2014). Isolation, identification, and comparatative analysis of SDA and DTM for dermatophytes from clinical samples in a tertiary care hospital. Journal of Dental and Medical Sciences, 13(11), 68-73. https://doi.org/10.9790/0853-131126873

Puspitasari, P. (2014). Pengaruh minyak serai wangi (Cymbopogon nardus L. Rendle) terhadap pertumbuhan Microsporum canis secara in vitro (Skripsi). Fakultas Kedokteran Hewan, Institut Pertanian Bogor.

Putriningsih, P. A. S. \& Arjentinia, I. P. G. Y. (2018). Identifikasi spesies fungi Microsporum gypseum dan Microsporum nanum penyebab ringworm pada sapi bali. Jurnal Veteriner, 19(2), 177-182. https://doi.org/10.19087/jveteriner.2018.19.2.177

Retnowati, Y., Uno, W. D., Kumaji, S. \& Humokor, Y. (2010). Pertumbuhan kapang Monascus purpureus, Aspergillus flavus, dan Penicilium sp. pada media beras, jagung, dan kombinasi beras jagung. Jurnal Sainstek 5(3), 1-7.

Rosana, Y., Matsuzawa, T., Gonoi, T., \& Karuniawati, A. (2014). Modified slide culture method for faster and easier identification of dermatophytes. Microbiology Indonesia, 8(3), 135-139. https://doi.org/10.5454/mi.8.3.7

Sanito, R., Novembrianto, R. \& Pandebesie, E. S. (2015). Kajian penentuan fase pertumbuhan kapang dan bakteri selulolitik pada media pertumbuhan. Prosiding Seminar Nasional Manajemen Teknologi XXII. Program Studi MMT-ITS.

Savitri, F. R. (2010). Efek antifungi ekstrak biji jinten hitam (Nigella sativa) terhadap pertumbuhan Microsporum gypseum secara in vitro (Skripsi). Fakultas Kedokteran, Universitas Sebelas Maret.

Shapourzadeh, A., Verki, N. R., Atyabi, S. M., Ghahfarokhi, M. S., Jahanshiri, Z., Irani, S. \& Abyaneh, M. R. (2016). Inhibitory effects of cold atmospheric plasma on the growth, ergosterol biosynthesis, and keratinase activity in Trichophyton rubrum. Journal Archives of Biochemistry and Biophysics, 608, 27-33. https://doi.org/10.1016/j.abb.2016.07.012 
Rufaidah dkk., 2020

Shimamura, T., Kubota, N. \& Shibuya, K. (2012). Animal model of dermatophytosis. Journal of Biomedicine and Biotechnology, 11, 1-7. https://doi.org/10.1155/2012$/ 125384$

Soeharsono. (2002). Zoonosis: Penyakit Menular dari Hewan ke Manusia. Kanisius. 